\title{
Cubitanoids and Cembranoids from the Soft Coral Sinularia nanolobata
}

\author{
Chih-Hua Chao ${ }^{1,2,+}$, Chia-Yun Wu ${ }^{3,+}$, Chiung-Yao Huang ${ }^{3}$, Hui-Chun Wang ${ }^{3,4,5}$, \\ Chang-Feng Dai ${ }^{6}$, Yang-Chang $\mathrm{Wu}^{1,2,7}$ and Jyh-Horng Sheu ${ }^{3,5,8,9, *}$ \\ 1 School of Pharmacy, China Medical University, Taichung 404, Taiwan; chchao@mail.cmu.edu.tw (C.-H.C.); \\ yachwu@mail.cmu.edu.tw (Y.-C.W.) \\ 2 Chinese Medicine Research and Development Center, China Medical University Hospital, \\ Taichung 404, Taiwan \\ 3 Department of Marine Biotechnology and Resources, National Sun Yat-sen University, Kaohsiung 804, \\ Taiwan; eleahant111@yahoo.com.tw (C.-Y.W.); huangcy@mail.nsysu.edu.tw (C.-Y.H.); \\ wanghc@kmu.edu.tw (H.-C.W.) \\ 4 Ph.D. Program in Translational Medicine, College of Medicine and Ph.D. Program in Toxicology, \\ College of Pharmacy, Kaohsiung Medical University, Kaohsiung 807, Taiwan \\ 5 Graduate Institute of Natural Products, Kaohsiung Medical University, Kaohsiung 807, Taiwan \\ 6 Institute of Oceanography, National Taiwan University, Taipei 112, Taiwan; corallab@ntu.edu.tw \\ 7 Center for Molecular Medicine, China Medical University Hospital, Taichung 404, Taiwan \\ 8 Department of Medical Research, China Medical University Hospital, China Medical University, \\ Taichung 404, Taiwan \\ 9 Frontier Center for Ocean Science and Technology, National Sun Yat-sen University, Kaohsiung 804, Taiwan \\ * Correspondence: sheu@mail.nsysu.edu.tw; Tel.: +886-7-5252000 (ext. 5030); Fax: +886-7-5255020 \\ + These authors contributed equally to this work.
}

Academic Editor: Vassilios Roussis

Received: 21 June 2016; Accepted: 29 July 2016; Published: 9 August 2016

\begin{abstract}
Two new cubitanoids, nanoculones A and B (1 and 2), and three new cembranoids, nanolobols A-C (3-5), as well as six known compounds, calyculone I (6), sinulariuol A (7), sinulariols C, D, H, and J (8-11), were isolated from the soft coral Sinularia nanolobata, collected off the coast of the eastern region of Taiwan. Their structures were elucidated on the basis of extensive spectroscopic analysis. Cytotoxicity of compounds $\mathbf{1 - 1 1}$ was evaluated. The nitric oxide (NO) inhibitory activity of selected compounds was further measured by assay of lipopolysaccharide (LPS)-stimulated NO production in activated RAW264.7 cells. The results showed that none of 1-11 exhibited cytotoxicity against the tested cancer cell lines, whereas compound $\mathbf{8}$ was found to significantly reduce $\mathrm{NO}$ production.
\end{abstract}

Keywords: Sinularia; cubitane; nanoculones A and B; nanolobols A-C

\section{Introduction}

Cubitane-type diterpenoids are a rare group of compounds that are isolated from termites, soft corals, and plants [1]. The first cubitanoid, (+)-cubitene, was discovered from the secretion gland of the termite Cubitermes umbratus [2]. Afterward, an array of cubitanoids, namely, calyculones A-I, were found from soft corals of genus Eunicea [3-5]. In some plants, cubitene was detected by gas chromatography-mass spectrometry (GC/MS) from their volatile oils [6]. In the aforementioned three sources, cubitanoids were usually found in company with cembranoids [1], which represent a large group of compounds in soft coral [7-10]. The origin of cubitanoids was speculated to be associated with the co-occurring cembranoids based on a photochemical interconversion [4].

Our previous study on the soft coral Sinularia nanolobata (Verseveldt), collected off the coast of the most southern tip of Taiwan, resulted in the characterization of caryophyllane- and xeniaphyllane-type 
terpenoids [11]. Another collection of the same species off the coast of northern region of Taiwan led to the isolation of a novel C18 terpenoid [12]. Herein, we report the investigation on the chemical constituents of $S$. nanolobata, collected off the coast of the eastern region of Taiwan, which led to the isolation of two new cubitanoids, nanoculones A and B (1 and 2), three new cembranoids, nanolobols A-C (3-5) (Figure 1), as well as six known compounds (6-11). The cytotoxicity of compounds 1-11 against cancer cell lines P388 (murine leukemia), K562 (human erythromyeloblastoid leukemia), and HT-29 (human colon adenocarcinoma) was evaluated. In addition, the nitric oxide inhibitory activities of compounds 1-4, 6-8, 10, and 11 were further evaluated by assay of lipopolysaccharide (LPS)-stimulated NO production in activated RAW264.7 cells.

\section{Results and Discussion}

The EtOH extract of $S$. nanolobata was concentrated and partitioned with EtOAc, successively. The resulting EtOAc layer was separated repeatedly by column chromatography and High-performance liquid chromatography (HPLC) to afford five new diterpenoids (1-5) (Figure 1) and six known compounds (6-11). The known compounds were identified as calyculone I (6) [5], sinulariuol A (7) [13], sinulariols C, D, H, and J (8-11) [13], by comparison of their spectroscopic data with those reported in the literature. A single-crystal X-ray analysis was performed on 6, which led to the establishment of the absolute configuration of 6 (Figure 2).

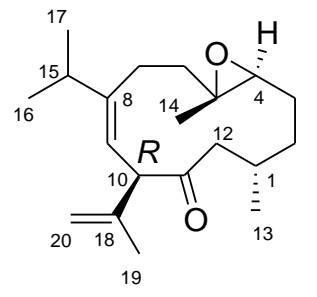

1

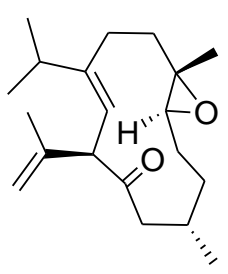

2

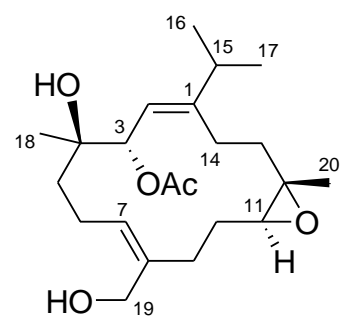

3
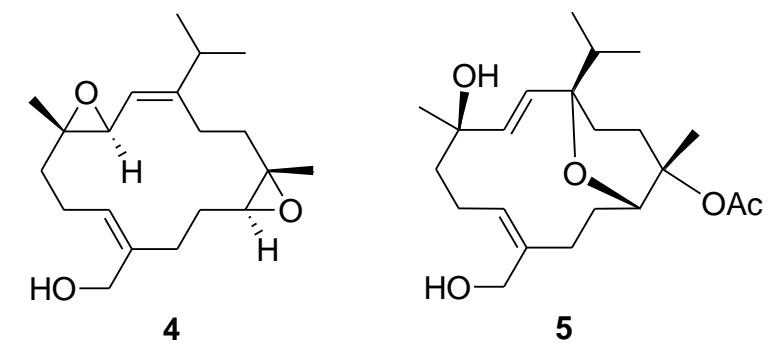

Figure 1. Structures of compounds 1-5.

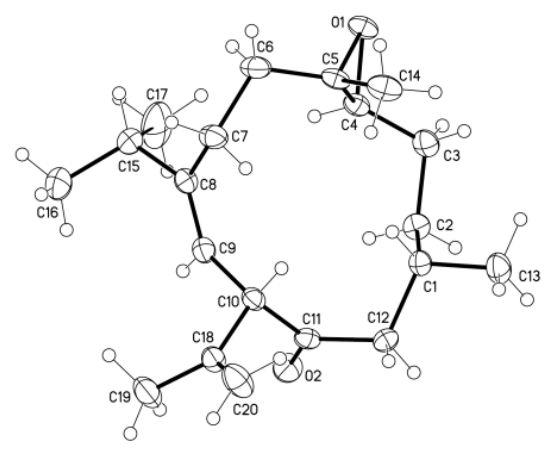

Figure 2. X-ray structure of 6 .

Inspection of the high resolution electrospray ionization mass spectroscopy (HRESIMS) (Supplementary Materials, Figure S1) and ${ }^{13} \mathrm{C}$ nuclear magnetic resonance (NMR) spectroscopic 
data allowed the establishment of a molecular formula of $\mathrm{C}_{20} \mathrm{H}_{32} \mathrm{O}_{2}$ for $\mathbf{1}$, requiring five degrees of unsaturation. The IR spectrum showed the presence of carbonyl group $\left(1710 \mathrm{~cm}^{-1}\right)$. The NMR spectra of 1 (Figures S2 and S3) displayed signals attributable to a ketone $\left[\delta_{\mathrm{C}} 209.7(\mathrm{qC})\right]$, a trisubstituted double bond [ $\delta_{\mathrm{C}} 147.1(\mathrm{qC}), \delta_{\mathrm{C}} 120.4(\mathrm{CH}) ; \delta_{\mathrm{H}} 5.45(1 \mathrm{H}, \mathrm{d}, J=10.0 \mathrm{~Hz})$ ], a disubstituted double bond $\left[\delta_{\mathrm{C}} 143.0(\mathrm{qC}), \delta_{\mathrm{C}} 112.6\left(\mathrm{CH}_{2}\right) ; \delta_{\mathrm{H}} 4.85\right.$ and 4.80 (each $\left.\left.1 \mathrm{H}, \mathrm{s}\right)\right]$, and a trisubstituted epoxide $\left[\delta_{\mathrm{C}} 62.3(\mathrm{qC}), \delta_{\mathrm{C}} 62.5(\mathrm{CH}) ; \delta_{\mathrm{H}} 2.77(1 \mathrm{H}, \mathrm{dd}, J=9.2,3.6 \mathrm{~Hz})\right]$ (Table 1), which accounted for four degrees of unsaturation and two oxygen atoms in the molecular formula. Thus, the structure of 1 should contain an additional ring. The above data, in conjunction with a highly deshielded proton at $\delta_{\mathrm{H}} 4.21$ $(1 \mathrm{H}, \mathrm{d}, J=10.0 \mathrm{~Hz}, \mathrm{H}-10)$ coupled by the olefinic H-9, were reminiscent of a cubitane skeleton [1-5].

Table 1. ${ }^{1} \mathrm{H}$ and ${ }^{13} \mathrm{C}$ NMR spectroscopic data of compounds $\mathbf{1}$ and 2.

\begin{tabular}{|c|c|c|c|c|}
\hline \multirow{2}{*}{ Position } & \multicolumn{2}{|c|}{1} & \multicolumn{2}{|c|}{2} \\
\hline & $\delta_{\mathrm{H}}(J \text { in } \mathrm{Hz})^{a}$ & $\delta_{C}$ (mult.) ${ }^{b}$ & $\delta_{\mathrm{H}}(J \text { in } \mathrm{Hz})^{a}$ & $\delta_{C}$ (mult.) $^{b}$ \\
\hline 1 & $1.95 \mathrm{~m}$ & $27.8, \mathrm{CH}$ & $2.06 \mathrm{~m}$ & $29.2, \mathrm{CH}$ \\
\hline 2 & $1.54 \mathrm{~m}$ & $33.9, \mathrm{CH}_{2}$ & $\begin{array}{l}1.48 \mathrm{~m} \\
1.24 \mathrm{~m}\end{array}$ & $30.3, \mathrm{CH}_{2}$ \\
\hline 3 & $\begin{array}{l}1.98 \mathrm{~m} \\
1.30 \mathrm{~m}\end{array}$ & $25.9, \mathrm{CH}_{2}$ & $\begin{array}{l}1.93 \mathrm{~m} \\
1.24 \mathrm{~m}\end{array}$ & $24.9, \mathrm{CH}_{2}$ \\
\hline $\begin{array}{l}4 \\
5\end{array}$ & $2.77 \mathrm{dd}(9.2,3.6)$ & $\begin{array}{c}62.5, \mathrm{CH} \\
62.3, \mathrm{C}\end{array}$ & $2.61 \mathrm{dd}(10.0,2.8)$ & $\begin{array}{c}64.6, \mathrm{CH} \\
60.2, \mathrm{C}\end{array}$ \\
\hline 6 & $\begin{array}{l}2.30 \mathrm{~m} \\
1.39 \mathrm{~m}\end{array}$ & $35.7, \mathrm{CH}_{2}$ & $\begin{array}{l}2.06 \mathrm{~m} \\
1.62 \mathrm{~m}\end{array}$ & $35.1, \mathrm{CH}_{2}$ \\
\hline 7 & $\begin{array}{l}2.58 \mathrm{~m} \\
2.10 \mathrm{~m}\end{array}$ & $25.9, \mathrm{CH}_{2}$ & $\begin{array}{l}2.21 \mathrm{~m} \\
2.09 \mathrm{~m}\end{array}$ & $27.5, \mathrm{CH}_{2}$ \\
\hline 8 & & 147.1, C & & 147.7, C \\
\hline 9 & $5.45 \mathrm{~d}(10.0)$ & $120.4, \mathrm{CH}$ & $5.20 \mathrm{~d}(10.8)$ & $119.3, \mathrm{CH}$ \\
\hline 10 & $4.21 \mathrm{~d}(10.0)$ & 57.7, CH & $4.08 \mathrm{~d}(10.8)$ & $60.5, \mathrm{CH}$ \\
\hline 11 & & 209.7, C & & 208.7, C \\
\hline 12 & $\begin{array}{c}2.63 \mathrm{dd}(14.8,6.4) \\
2.28 \mathrm{~m}\end{array}$ & $52.6, \mathrm{CH}_{2}$ & $\begin{array}{c}2.54 \mathrm{dd}(11.6,2.8) \\
1.68 \mathrm{~m}\end{array}$ & $48.4, \mathrm{CH}_{2}$ \\
\hline 13 & $0.89 \mathrm{~d}(6.4)$ & $20.6, \mathrm{CH}_{3}$ & $0.95 \mathrm{~d}(6.4)$ & $20.7, \mathrm{CH}_{3}$ \\
\hline 14 & $1.16 \mathrm{~s}$ & $19.0, \mathrm{CH}_{3}$ & $1.31, \mathrm{~s}$ & $18.0, \mathrm{CH}_{3}$ \\
\hline 15 & $2.40 \mathrm{~m}$ & $30.3, \mathrm{CH}$ & $2.87 \mathrm{~m}$ & $29.6, \mathrm{CH}$ \\
\hline 16 & $1.08 \mathrm{~d}(6.4)$ & $20.5, \mathrm{CH}_{3}$ & $1.07 \mathrm{~d}(7.0)$ & $21.7, \mathrm{CH}_{3}$ \\
\hline 17 & $0.98 \mathrm{~d}(6.4)$ & $23.0, \mathrm{CH}_{3}$ & $1.01 \mathrm{~d}(7.0)$ & $21.4, \mathrm{CH}_{3}$ \\
\hline 18 & & 143.0, C & & 147.7, C \\
\hline 19 & $1.70 \mathrm{~s}$ & $21.2, \mathrm{CH}_{3}$ & $1.75 \mathrm{~s}$ & $22.2, \mathrm{CH}_{3}$ \\
\hline 20 & $\begin{array}{l}4.85 \mathrm{~s} \\
4.80 \mathrm{~s}\end{array}$ & 112.6, $\mathrm{CH}_{2}$ & $\begin{array}{l}4.99 \mathrm{~s} \\
4.90 \mathrm{~s}\end{array}$ & $112.7, \mathrm{CH}_{2}$ \\
\hline
\end{tabular}

${ }^{a}$ Spectra recorded at $400 \mathrm{MHz}$ in $\mathrm{CDCl}_{3} ;{ }^{b}$ Spectra recorded at $100 \mathrm{MHz}$ in $\mathrm{CDCl}_{3}$.

On the basis of $\mathrm{H}-\mathrm{H}$ correlation spectroscopy (COSY) correlations of $\mathrm{H}_{2}-12 / \mathrm{H}-1 / \mathrm{H}_{2}-2 / \mathrm{H}_{2}-3 / \mathrm{H}-4$, $\mathrm{H}-1 / \mathrm{H}_{3}-13, \mathrm{H}_{2}-6 / \mathrm{H}_{2}-7, \mathrm{H}_{3}-16 / \mathrm{H}-15 / \mathrm{H}_{3}-17$, and $\mathrm{H}-9 / \mathrm{H}-10$, the spin systems were established as shown in Figure 3. An isopropyl was deduced to be attached at C-8 according to the heteronuclear multiple bond correlation (HMBC) correlations from $\mathrm{H}_{3}-16$ (or $\mathrm{H}_{3}-17$ ) to $\mathrm{C}-15, \mathrm{C}-17$ (or C-16), and C-8. A propen-2-yl fragment was assigned at C-10 based on the $\mathrm{HMBC}$ correlations from $\mathrm{H}_{3}-19$ to $\mathrm{C}-10$, C-18, and C-20. The methyl-substituted epoxide was assigned according to the HMBC correlations from $\mathrm{H}_{3}-14$ to C-4, C-5, and C-6. Accordingly, the planar structure of 1 was established and found to be the same as that of calyculone I (6) [5]. 


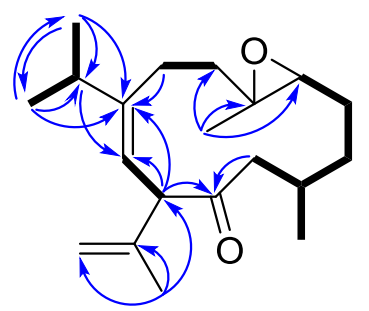

1

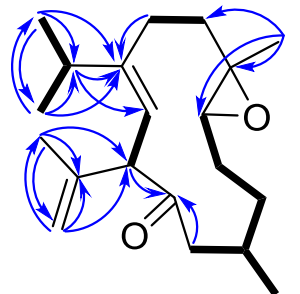

2

$-{ }^{1} \mathrm{H}-{ }^{1} \mathrm{H} \cos Y$

$\rightarrow \mathrm{HMBC}$

Figure 3. Selected ${ }^{1} \mathrm{H}-{ }^{1} \mathrm{H}$ COSY and HMBC correlations of $\mathbf{1}$ and 2.

The nuclear Overhauser effect spectroscopy (NOESY) experiment was performed and its correlations were interpreted for the elucidation of the relative configuration of $\mathbf{1}$ (Figure 4). An NOE correlation between $\mathrm{H}-9$ and $\mathrm{H}_{3}-16$ suggested an $E$ geometry for C-8/C-9 double bond. The absence of an NOE cross peak between $\mathrm{H}_{3}-14$ and $\mathrm{H}-4$ along with the presence of a correlation between $\mathrm{H}-4$ and $\mathrm{H}-6 \mathrm{~b}$ conducted to assign a trans geometry for 4,5-epoxide. The observed NOE correlations of $\mathrm{H}-10 / \mathrm{H}-4, \mathrm{H}-4 / \mathrm{H}-7 \mathrm{a}$ and $\mathrm{H}-10 / \mathrm{H}-7$ a suggested the same orientation of $\mathrm{H}-10$ and $\mathrm{H}-4$ in the molecule, whereas a correlation of $\mathrm{H}_{3}-14 / \mathrm{H}-1$ disclosed that $\mathrm{H}-1$ is oriented opposite $\mathrm{H}-10$. Thus, 1 was deduced as a C-10 epimer of calyculone I (6).

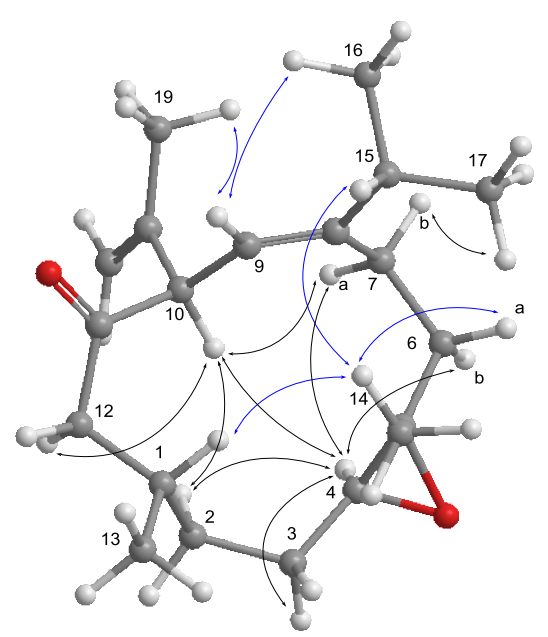

1

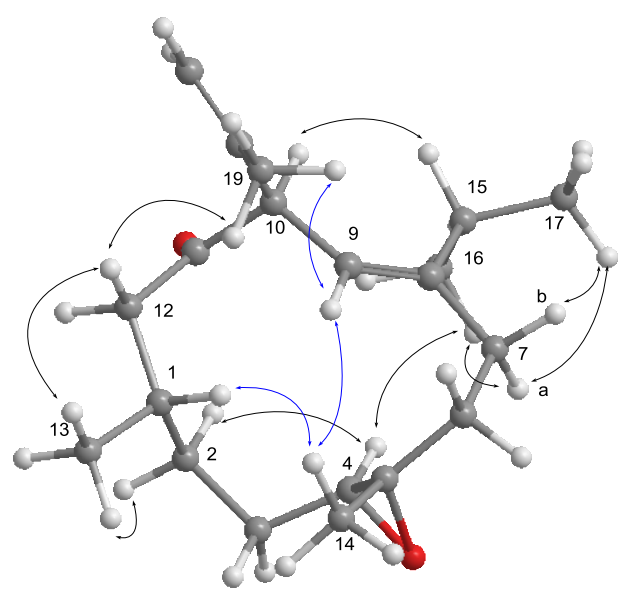

2

Figure 4. Selected NOE correlations of compounds 1 and 2.

Analysis of the ${ }^{13} \mathrm{C}$ NMR and HRESIMS spectral data of 2 reveal the same molecular formula as that of 1 (Figures S4 and S6). The interpretation of NMR data and COSY and HMBC correlations (Figure 3) again showed that it is possibly a diastereomer or geometrical isomer of $\mathbf{1}$. The NOE experiment allowed the relative configuration of 2 to be defined. As shown in Figure 4, the NOE correlation of $\mathrm{H}-10 / \mathrm{H}-15$ as well as correlations of $\mathrm{H}-4 / \mathrm{H}_{3}-16$ and $\mathrm{H}_{3}-16 / \mathrm{H}-7$ a conducted to assign an $8 \mathrm{Z}$ olefin and a trans epoxide. Moreover, correlations of $\mathrm{H}-1 / \mathrm{H}_{3}-14$ and $\mathrm{H}_{3}-14 / \mathrm{H}-9$ suggested that $\mathrm{H}-1$ and $\mathrm{H}_{3}-14$ were oriented on opposite face to $\mathrm{H}-10$. Consequently, 2 was determined as an $8 \mathrm{Z}$ epimer of $\mathbf{1}$.

The HRESIMS of 3 displayed a sodiated molecular ion peak at $m / z 403.2456[\mathrm{M}+\mathrm{Na}]^{+}$(Figure S7), indicative of a molecular formula of $\mathrm{C}_{22} \mathrm{H}_{36} \mathrm{O}_{5}$, suggesting five degrees of unsaturation. Its IR spectrum showed characteristic absorptions due to the presence of hydroxy $\left(3437 \mathrm{~cm}^{-1}\right)$ and ester 
carbonyl $\left(1732 \mathrm{~cm}^{-1}\right)$ groups. The latter was determined as an acetoxy functionality based on the NMR resonances at $\delta_{\mathrm{C}} 170.9(\mathrm{C}), \delta_{\mathrm{C}} 21.4\left(\mathrm{CH}_{3}\right)$, and $\delta_{\mathrm{H}} 2.07$ (Table 2). The ${ }^{13} \mathrm{C}$ NMR spectrum (Figure S9) also showed characteristic signals composed of two olefins [ $\delta_{\mathrm{C}} 151.8(\mathrm{C}), 137.7(\mathrm{C})$, $131.7(\mathrm{CH})$, and $118.2(\mathrm{CH})]$, an epoxide $\left[\delta_{\mathrm{C}} 62.2(\mathrm{CH})\right.$ and $\left.61.6(\mathrm{C})\right]$, and three oxygen-bearing carbons [ $\delta_{\mathrm{C}} 74.8(\mathrm{CH}), 74.0(\mathrm{C})$, and $\left.59.5\left(\mathrm{CH}_{2}\right)\right]$. The above functionalities accounted for four of the five degrees of unsaturation, implying 3 to be monocyclic. Except for the acetyl group, its NMR data resemble those of sinulariol L [13], while 2D NMR interpretation revealed that 3 was a 3-O-acetyl analogue of sinulariol L. Analysis of NOE correlations of 3 ascertained that they shared the same relative configurations at C-3, C-4, C-11, and C-12, as well as the same geometries of C-1 and C-7 double bonds.

Table 2. ${ }^{1} \mathrm{H}$ and ${ }^{13} \mathrm{C}$ NMR spectroscopic data of 3-5.

\begin{tabular}{|c|c|c|c|c|c|c|}
\hline \multirow{2}{*}{ Position } & \multicolumn{2}{|c|}{3} & \multicolumn{2}{|l|}{4} & \multicolumn{2}{|l|}{5} \\
\hline & $\delta_{\mathrm{H}}(J \text { in } \mathrm{Hz})^{a}$ & $\delta_{C}(\text { mult. })^{b}$ & $\delta_{\mathrm{H}}(J \text { in } \mathrm{Hz})^{a}$ & $\delta_{\mathrm{C}}$ (mult.) ${ }^{b}$ & $\delta_{\mathrm{H}}(J \text { in } \mathrm{Hz})^{c}$ & $\delta_{C}$ (mult.) ${ }^{d}$ \\
\hline 1 & & $151.8, \mathrm{C}$ & & $151.8, \mathrm{C}$ & & $78.3, \mathrm{C}$ \\
\hline 2 & $5.09 \mathrm{~d}(10.0)$ & $118.2, \mathrm{CH}$ & $4.99 \mathrm{~d}(6.8)$ & $119.2, \mathrm{CH}$ & $5.67 \mathrm{~d}(16.0)$ & $126.8, \mathrm{CH}$ \\
\hline 3 & $5.49 \mathrm{~d}(10.0)$ & $74.8, \mathrm{CH}$ & $3.33 \mathrm{~d}(6.8)$ & $59.5, \mathrm{CH}$ & $6.01 \mathrm{~d}(16.0)$ & $140.8, \mathrm{CH}$ \\
\hline 4 & & $74.0, \mathrm{C}$ & & 61.3, C & & $73.5, \mathrm{C}$ \\
\hline \multirow[t]{2}{*}{5} & $1.70 \mathrm{~m}$ & $36.6, \mathrm{CH}_{2}$ & $2.08 \mathrm{~m}$ & $38.0, \mathrm{CH}_{2}$ & $1.96 \mathrm{~m}$ & 43.6, $\mathrm{CH}_{2}$ \\
\hline & $1.59 \mathrm{~m}$ & & $1.47 \mathrm{~m}$ & & $1.68 \mathrm{~m}$ & \\
\hline \multirow[t]{2}{*}{6} & $2.61 \mathrm{~m}$ & 23.6, $\mathrm{CH}_{2}$ & $2.31 \mathrm{~m}$ & $22.0, \mathrm{CH}_{2}$ & $2.35 \mathrm{~m}$ & 23.6, $\mathrm{CH}_{2}$ \\
\hline & $2.12 \mathrm{~m}$ & & $2.09 \mathrm{~m}$ & & $2.21 \mathrm{~m}$ & \\
\hline 7 & $5.47 \mathrm{t}(7.6)$ & 131.7, CH & $5.48 \mathrm{t}(7.6)$ & $129.9, \mathrm{CH}$ & $5.32 \mathrm{t}(7.5)$ & $134.2, \mathrm{CH}$ \\
\hline 8 & & $137.7, \mathrm{C}$ & & 137.6, C & & $135.0, \mathrm{C}$ \\
\hline \multirow[t]{2}{*}{9} & $2.34 \mathrm{~m}$ & $34.7, \mathrm{CH}_{2}$ & $2.61 \mathrm{~m}$ & 32.6, $\mathrm{CH}_{2}$ & $2.33 \mathrm{~m}$ & $34.6, \mathrm{CH}_{2}$ \\
\hline & $2.23 \mathrm{~m}$ & & $2.05 \mathrm{~m}$ & & $2.12 \mathrm{~m}$ & \\
\hline \multirow[t]{2}{*}{10} & $2.15 \mathrm{~m}$ & 24.6, $\mathrm{CH}_{2}$ & $2.14 \mathrm{~m}$ & $24.8, \mathrm{CH}_{2}$ & $1.66 \mathrm{~m}$ & $27.3, \mathrm{CH}_{2}$ \\
\hline & $1.44 \mathrm{~m}$ & & $1.37 \mathrm{~m}$ & & $1.52 \mathrm{~m}$ & \\
\hline 11 & $3.20 \mathrm{dd}(9.6,2.8)$ & $62.2, \mathrm{CH}$ & $2.73 \mathrm{dd}(10.0,4.0)$ & $61.9, \mathrm{CH}$ & $3.61 \mathrm{dd}(8.0,1.5)$ & $72.6, \mathrm{CH}$ \\
\hline 12 & & 61.6, C & & $61.3, \mathrm{C}$ & & $81.9, \mathrm{C}$ \\
\hline \multirow[t]{2}{*}{13} & $2.10 \mathrm{~m}$ & $40.1, \mathrm{CH}_{2}$ & $2.17 \mathrm{~m}$ & $38.3, \mathrm{CH}_{2}$ & $2.46 \mathrm{dt}(11.5,3.5)$ & $31.5, \mathrm{CH}_{2}$ \\
\hline & $0.98 \mathrm{~m}$ & & $1.19 \mathrm{~m}$ & & $1.91 \mathrm{~m}$ & \\
\hline \multirow[t]{2}{*}{14} & $2.30 \mathrm{~m}$ & 27.0, $\mathrm{CH}_{2}$ & $2.17 \mathrm{~m}$ & 27.4, $\mathrm{CH}_{2}$ & $1.86 \mathrm{~m}$ & 26.4, $\mathrm{CH}_{2}$ \\
\hline & $1.97 \mathrm{~m}$ & & & & $1.49 \mathrm{~m}$ & \\
\hline 15 & $2.34 \mathrm{~m}$ & $35.3, \mathrm{CH}$ & $2.27 \mathrm{~m}$ & $34.0, \mathrm{CH}$ & $1.85 \mathrm{~m}$ & 39.1, CH \\
\hline 16 & $1.03 \mathrm{~d}(6.8)$ & $21.8, \mathrm{CH}_{3}$ & $1.03 \mathrm{~d}(6.8)$ & $21.8, \mathrm{CH}_{3}$ & $0.77 \mathrm{~d}(7.0)$ & $17.2, \mathrm{CH}_{3}$ \\
\hline 17 & $1.03 \mathrm{~d}(6.8)$ & $22.1, \mathrm{CH}_{3}$ & $1.04 \mathrm{~d}(6.8)$ & $22.3, \mathrm{CH}_{3}$ & $0.92 \mathrm{~d}(7.0)$ & $16.5, \mathrm{CH}_{3}$ \\
\hline 18 & $1.13 \mathrm{~s}$ & $23.9, \mathrm{CH}_{3}$ & $1.25 \mathrm{~s}$ & $18.0, \mathrm{CH}_{3}$ & $1.30 \mathrm{~s}$ & $29.4, \mathrm{CH}_{3}$ \\
\hline \multirow[t]{2}{*}{19} & $4.36 \mathrm{~d}(12.8)$ & $59.5, \mathrm{CH}_{2}$ & $4.29 \mathrm{~d}(12.0)$ & $58.8, \mathrm{CH}_{2}$ & $4.24 \mathrm{~d}(12.0)$ & $60.2, \mathrm{CH}_{2}$ \\
\hline & $4.01 \mathrm{~d}(12.8)$ & & $4.18 \mathrm{~d}(12.0)$ & & $4.10 \mathrm{~d}(12.0)$ & \\
\hline \multirow{3}{*}{$\begin{array}{c}20 \\
\text { OAc }\end{array}$} & $1.28 \mathrm{~s}$ & $16.3 \mathrm{CH}_{3}$ & $1.29 \mathrm{~s}$ & $16.5 \mathrm{CH}_{3}$ & $1.44 \mathrm{~s}$ & $16.8 \mathrm{CH}_{3}$ \\
\hline & & $170.9, \mathrm{C}$ & & & & $170.2, \mathrm{C}$ \\
\hline & $2.07 \mathrm{~s}$ & 21.4, $\mathrm{CH}_{3}$ & & & $1.98 \mathrm{~s}$ & $22.4, \mathrm{CH}_{3}$ \\
\hline
\end{tabular}

${ }^{a}$ Spectra recorded at $400 \mathrm{MHz}$ in $\mathrm{CDCl}_{3} ;{ }^{b}$ Spectra recorded at $100 \mathrm{MHz}$ in $\mathrm{CDCl}_{3} ;{ }^{c}$ Spectra recorded at $500 \mathrm{MHz}$ in $\mathrm{CDCl}_{3} ;{ }^{d}$ Spectra recorded at $125 \mathrm{MHz}$ in $\mathrm{CDCl}_{3}$.

The molecular formula of 4 was determined as $\mathrm{C}_{20} \mathrm{H}_{32} \mathrm{O}_{3}$ by the analysis of its HRESIMS and ${ }^{13} \mathrm{C}$ NMR spectrum (Figures S10 and S12). Its NMR spectroscopic data (Table 2) also were found to be mostly similar to those of sinulariol L [13]. Inspection of ${ }^{1} \mathrm{H}$ and ${ }^{13} \mathrm{C}$ NMR data of 4 suggested the presence of two epoxides [ $\delta_{\mathrm{C}} 61.9(\mathrm{CH}), 61.3(\mathrm{C} \times 2)$, and $59.5(\mathrm{CH}) ; \delta_{\mathrm{H}} 3.33(1 \mathrm{H}, \mathrm{d}, J=6.8 \mathrm{~Hz})$ and $2.73(1 \mathrm{H}, \mathrm{dd}, J=10.0,4.0 \mathrm{~Hz})]$. These data suggested 4 to be a 3,4-epoxide analogue of sinulariol $\mathrm{L}$, which was corroborated by the HMBC correlations from $\mathrm{H}_{3}-18$ to C-3, C-4, and C-5 as well as COSY correlation between $\mathrm{H}-2$ and $\mathrm{H}-3$. The $1 E$ and $7 \mathrm{Z}$ geometries were inferred according to the NOE correlations of $\mathrm{H}-2 / \mathrm{H}-15$ and $\mathrm{H}_{2}-19 / \mathrm{H}-6 \mathrm{a}$, while correlations of $\mathrm{H}_{3}-18 / \mathrm{H}-2$ and $\mathrm{H}-11 / \mathrm{H}-13 \mathrm{~b}$ suggested the trans geometries for both epoxides (Figure 5). The relative configurations at C-3, C-4, $\mathrm{C}-11$, and $\mathrm{C}-12$ were determined by further analysis of NOE correlations. The NOE correlations of $\mathrm{H}-3 / \mathrm{H}-6 \mathrm{a}, \mathrm{H}-3 / \mathrm{H}-7, \mathrm{H}-3 / \mathrm{H}-13 \mathrm{~b}$, and $\mathrm{H}-11 / \mathrm{H}-13 \mathrm{~b}$ indicated the spatial proximity among these protons and, thus, a $3 S^{*}, 4 S^{*}, 11 S^{*}, 12 S^{*}$-configuration was determined. 

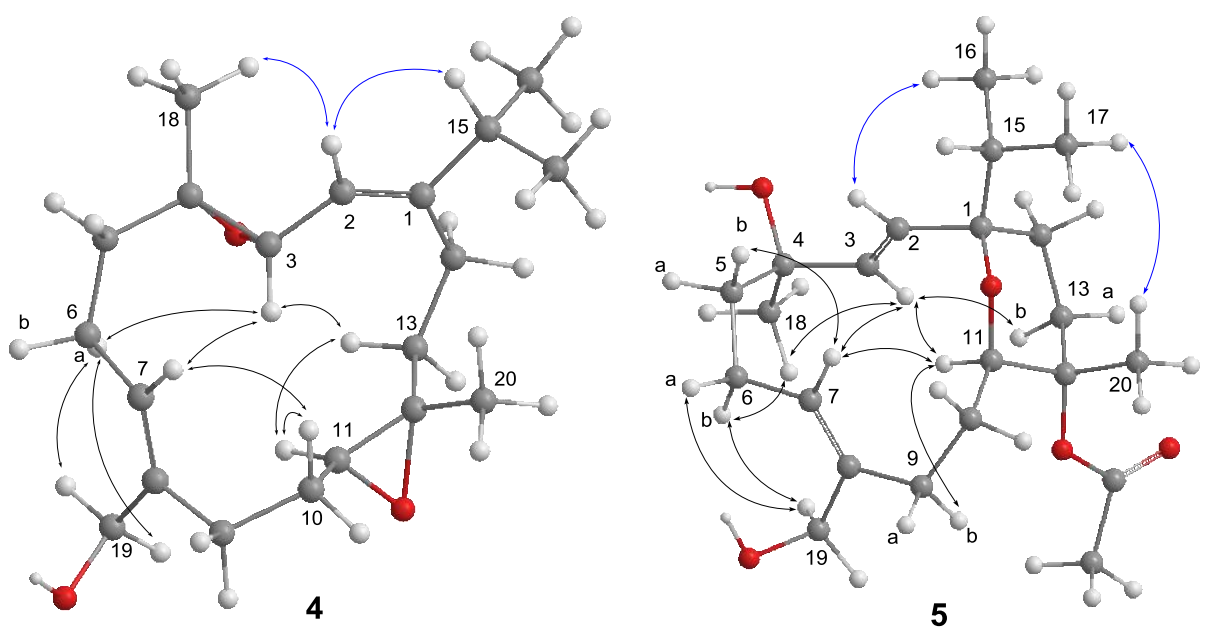

Figure 5. Selected NOE correlations of 4 and 5.

Compound 5 has a molecular formula of $\mathrm{C}_{22} \mathrm{H}_{36} \mathrm{O}_{5}$ as determined by HRESIMS and ${ }^{13} \mathrm{C}$ NMR spectrum (Figures S13 and S15). The NMR data of $\mathbf{5}$ (Table 2) substantially resemble those of sinulariol $\mathrm{J}$ [13], except for the presence of an additional acetyl group featured resonances at $\delta_{\mathrm{C}} 170.2(\mathrm{C}), \delta_{\mathrm{C}} 22.4$ $\left(\mathrm{CH}_{3}\right)$, and $\delta_{\mathrm{H}} 1.98(3 \mathrm{H}, \mathrm{s})$, suggesting 5 to be an $\mathrm{O}$-acetyl analogue of sinulariol $\mathrm{J}$. The downfield-shifted $\mathrm{C}-12\left(\delta_{\mathrm{C}} 81.9(\mathrm{C})\right.$ and $\mathrm{H}_{3}-20\left(\delta_{\mathrm{H}} 1.44\right)$ and the $\mathrm{HMBC}$ correlations from $\mathrm{H}_{3}-20$ to $\mathrm{C}-11, \mathrm{C}-12$, and $\mathrm{C}-13$ evidenced that this acetoxy group should be attached at $\mathrm{C}-12$. The $2 E$ and $7 Z$ geometries were determined to be the same as those of sinulariol $\mathrm{J}$ according to the large coupling constant $(J=16.0 \mathrm{~Hz})$ between $\mathrm{H}-2$ and $\mathrm{H}-3$, as well as NOE correlations of $\mathrm{H}_{2}-19 / \mathrm{H}_{2}-6$ (Figure 5). In addition, NOE correlations of $\mathrm{H}-3 / \mathrm{H}-11$ and $\mathrm{H}-3 / \mathrm{H}_{3}-18$ suggested they were oriented on the same face, and arbitrarily assigned as $\alpha$-orientation. The isopropyl group and $\mathrm{H}_{3}-20$ were, thus, assigned as $\beta$-orientation based on the correlations of $\mathrm{H}-2 / \mathrm{H}_{3}-16$ and $\mathrm{H}_{3}-17 / \mathrm{H}_{3}-20$. Consequently, an $1 R^{*}, 4 R^{*}, 11 R^{*}, 12 S^{*}$-configuration was assigned for $\mathbf{5}$. Moreover, the NMR spectroscopic data of six known compounds 6-11 (Figure 6) were found to be identical to those of known compounds based on the comparison of their physical and spectroscopic data with those reported in the literature [5,13].<smiles>C=C(C)[C@H]1/C=C(/C(C)C)CC[C@@]2(C)O[C@H]2CC[C@@H](C)CC1=O</smiles>

6

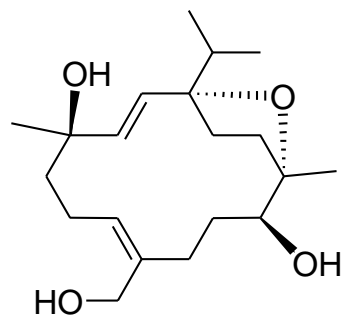

9

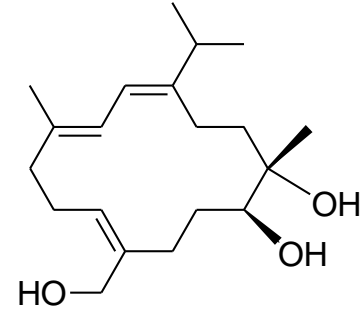

7

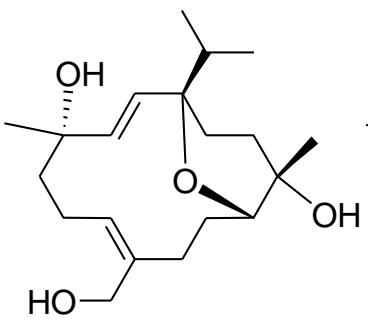

10

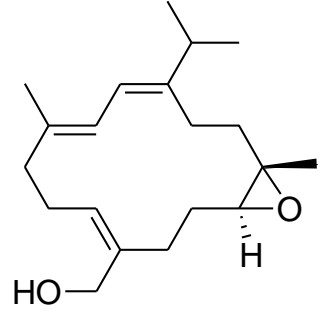

8

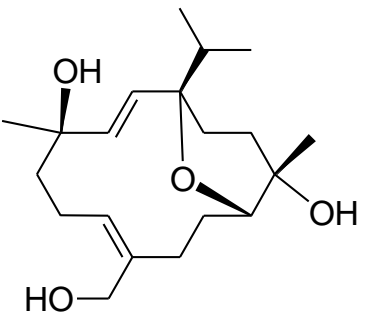

11

Figure 6. Structures of compounds 6-11. 
Compounds 1-11 were evaluated for cytotoxicity activities against P388, K562, and HT-29 cell lines using the Alamar Blue assay. The result showed that they are not cytotoxic against the above three cancer cell lines. In addition, the nitric oxide (NO) inhibitory activities of compounds 1-4, 6-8, 10, and 11 were further evaluated by assay of LPS-stimulated NO production in activated RAW264.7 cells, as shown in Figure 7. The results indicated that compounds 2, 6, and 8 could effectively reduce the levels of $\mathrm{NO}$ to $32.6 \%, 8.0 \%$, and $2.3 \%$, respectively, at a concentration of $100 \mu \mathrm{M}$. Moreover, compound 8 at a concentration of $50 \mu \mathrm{M}$ exhibited good inhibitory activity compared to the positive control aminoguanidine (AG), and the level of NO was also reduced significantly to $19.6 \%$, while giving a $104.6 \%$ retention of cell viability. Thus, compound 8 is a promising metabolite which may become a lead compound in the future anti-inflammatory drug development.
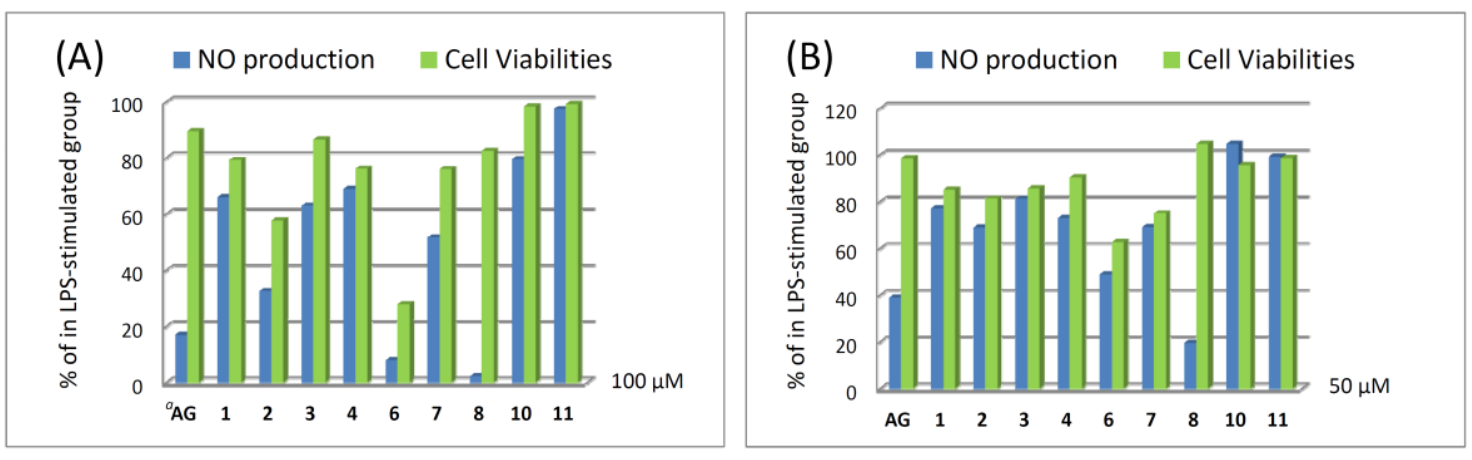

Figure 7. Nitric oxide (NO) production and cell viabilities of compounds 1-4, 6-8, 10, and 11 in LPS-stimulated RAW264.7 cells (A) at $100 \mu \mathrm{M}$ (B) at $50 \mu \mathrm{M}$. ${ }^{a} \mathrm{AG}$ : aminoguanidine is used as a positive control.

\section{Experimental Section}

\subsection{General Experimental Procedures}

Optical rotations were measured on a JASCO P-1020 digital polarimeter (JASCO Corporation, Tokyo, Japan). IR spectra were recorded on a JASCO FT/IR-4100 infrared spectrophotometer (JASCO Corporation). The ${ }^{1} \mathrm{H}$ NMR and ${ }^{13} \mathrm{C}$ NMR spectra were recorded on a Varian $400 \mathrm{MR}$ NMR $(400 \mathrm{MHz}$ for ${ }^{1} \mathrm{H}$ and $100 \mathrm{MHz}$ for ${ }^{13} \mathrm{C}$ ) and a Varian Unity INOVA500 FT-NMR (500 MHz for ${ }^{1} \mathrm{H}$ and $125 \mathrm{MHz}$ for ${ }^{13} \mathrm{C}$ ) instruments (Varian Inc., Palo Alto, CA, USA). The chemical shifts were referenced to the solvent residue of $\mathrm{CDCl}_{3}\left(\delta_{\mathrm{H}} 7.265 \mathrm{ppm}\right.$ and $\left.\delta_{\mathrm{C}} 77.0 \mathrm{ppm}\right)$. The high-resolution mass spectra were acquired via a Bruker APEX II mass spectrometer with an ESI ionization source (Bruker, Bremen, Germany).

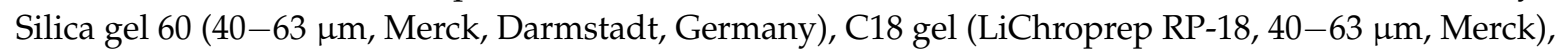
and Sephadex LH-20 (GE Healthcare, Uppsala, Sweden) were used for column chromatography. Thin-layer chromatography (TLC) analysis was performed on a precoated silica gel plates (Kieselgel $60 \mathrm{~F}_{254}, 0.25 \mathrm{~mm}$, Merck). High-performance liquid chromatography (HPLC) was performed using a Shimadzu LC-10AT VP series pump equipped with a UV detector (Shimadzu, Milan, Italy) and a semipreparative RP-18 column (5 $\mu \mathrm{m}, 250 \times 10$ mm, Hibar Purospher RP-18e, Merck).

\subsection{Animal Material}

The soft coral Sinularia nanolobata was collected off the coast of Jihui Fishing Port, Taitung county, Taiwan (latitude: $23^{\circ} 07^{\prime} \mathrm{N}$; longitude: $121^{\circ} 23^{\prime} \mathrm{E}$ ) in March 2013. The material was frozen at $-20^{\circ} \mathrm{C}$ until extraction in the laboratory. Species identification of this coral was performed by Prof. C.-F. Dai (National Taiwan University, Taiwan), while the voucher specimen (JiH-201303) was deposited at the Department of Marine Biotechnology and Resources, National Sun Yat-sen University. 


\subsection{Extraction and Isolation}

The minced, wet tissues of $S$. nanolobata $(3.1 \mathrm{~kg})$ were extracted with $\mathrm{EtOH}(3 \mathrm{~L} \times 2)$. The extract was concentrated under reduced pressure and the residue was partitioned between EtOAc and $\mathrm{H}_{2} \mathrm{O}$. The EtOAc layer was dried over $\mathrm{Na}_{2} \mathrm{SO}_{4}$ and the resulting residue (27.9 g) was subjected to a silica gel column with a gradient of acetone and hexane in an increasing polarity (acetone-hexane, $2 \%$ to $100 \%$ ), and then a gradient of $\mathrm{MeOH}$ and acetone (MeOH-acetone, $2 \%$ to $100 \%$ ) to yield 18 fractions. Fraction 7 was chromatographed on a silica gel column with acetone/hexane $(6 \%)$ to yield two subfractions $7 \mathrm{a}$ and $7 \mathrm{~b}$. Subfraction $7 \mathrm{a}$ was purified by a $\mathrm{C} 18$ gel column $\left(\mathrm{MeOH}-\mathrm{H}_{2} \mathrm{O}, 90 \%\right)$, followed by semipreparative HPLC (MeOH-H $\left.\mathrm{H}_{2} \mathrm{O}, 78 \%\right)$ to yield compounds $\mathbf{1}(34.3 \mathrm{mg}), 2(12.0 \mathrm{mg})$ and 6 $(12.6 \mathrm{mg})$. Fraction 10 was purified by a Sephadex LH-20 column using acetone as eluent to obtain a mixture, which was further separated by silica gel column chromatography (acetone-hexane, $10 \%$ to $100 \%)$, C18 column chromatography $\left(\mathrm{MeOH}-\mathrm{H}_{2} \mathrm{O}, 90 \%\right)$, and semipreparative HPLC $\left(\mathrm{MeOH}-\mathrm{H}_{2} \mathrm{O}\right.$, $83 \%)$ to yield compounds $4(2.6 \mathrm{mg})$ and $8(5.5 \mathrm{mg})$. Fraction 14 was purified by a Sephadex LH-20 column (acetone, $100 \%)$ and semipreparative $\mathrm{HPLC}\left(\mathrm{MeOH}-\mathrm{H}_{2} \mathrm{O}, 80 \%\right)$ to yield compounds $3(5.2 \mathrm{mg})$ and $5(1.2 \mathrm{mg})$, and $\left(\mathrm{MeOH}-\mathrm{H}_{2} \mathrm{O}, 67 \%\right)$ to yield compounds $7(3.8 \mathrm{mg})$ and $9(6.4 \mathrm{mg})$. Fraction 15 was purified by a Sephadex LH-20 column using acetone as eluent to obtain a mixture, which was further separated by silica gel column chromatography (acetone-hexane, 20\% to 100\%), C18 column chromatography $\left(\mathrm{MeOH}-\mathrm{H}_{2} \mathrm{O}, 90 \%\right)$, and semipreparative $\mathrm{HPLC}\left(\mathrm{MeOH}-\mathrm{H}_{2} \mathrm{O}, 66 \%\right)$ to yield compounds $\mathbf{1 0}(2.9 \mathrm{mg})$ and $\mathbf{1 1}(2.6 \mathrm{mg})$.

Nanoculone A (1): colorless oil; $[\alpha]_{\mathrm{D}}^{25}+6\left(c 1.20, \mathrm{CHCl}_{3}\right)$; IR (neat) $v_{\max } 2962,1710,1644,1457$, 1379, and $895 \mathrm{~cm}^{-1} ;{ }^{13} \mathrm{C}$ and ${ }^{1} \mathrm{H}$ NMR data, see Table 1 ; ESIMS $\mathrm{m} / \mathrm{z} 327[\mathrm{M}+\mathrm{Na}]^{+} ;$HRESIMS $\mathrm{m} / \mathrm{z}$ 327.2298 [M + Na] $]^{+}$(calcd. for $\mathrm{C}_{20} \mathrm{H}_{32} \mathrm{O}_{2} \mathrm{Na}, 327.2300$ ).

Nanoculone B (2): colorless oil; $[\alpha]_{\mathrm{D}}^{25}+175\left(\right.$ c 0.49, $\left.\mathrm{CHCl}_{3}\right)$; IR (neat) $v_{\max } 2957,2866,1705,1455$, 1105, and $895 \mathrm{~cm}^{-1} ;{ }^{13} \mathrm{C}$ and ${ }^{1} \mathrm{H}$ NMR data, see Table 1 ; ESIMS $\mathrm{m} / \mathrm{z} 327[\mathrm{M}+\mathrm{Na}]^{+} ;$HRESIMS $\mathrm{m} / \mathrm{z}$ 327.2297 [M + Na] $]^{+}$(calcd. for $\left.\mathrm{C}_{20} \mathrm{H}_{32} \mathrm{O}_{2} \mathrm{Na}, 327.2300\right)$.

Nanolobol A (3): colorless oil; $[\alpha]_{\mathrm{D}}^{25}+3\left(c 1.30, \mathrm{CHCl}_{3}\right)$; IR (neat) $v_{\max } 3437,2957,2960,1732$, $1459,1372,1246,1020$, and $756 \mathrm{~cm}^{-1} ;{ }^{13} \mathrm{C}$ and ${ }^{1} \mathrm{H}$ NMR data, see Table 2; ESIMS $\mathrm{m} / z 403[\mathrm{M}+\mathrm{Na}]^{+}$; HRESIMS $m / z$ 403.2456 [M + Na] ${ }^{+}$(calcd. for $\mathrm{C}_{22} \mathrm{H}_{36} \mathrm{O}_{5} \mathrm{Na}, 403.2455$ ).

Nanolobol B (4): colorless oil; $[\alpha]_{\mathrm{D}}^{25}-67$ (c 0.65, $\left.\mathrm{CHCl}_{3}\right)$; IR (neat) $v_{\max } 3441,2923,2960,1731$, 1462, 1024, and $856 \mathrm{~cm}^{-1} ;{ }^{13} \mathrm{C}$ and ${ }^{1} \mathrm{H}$ NMR data, see Table 2; ESIMS $\mathrm{m} / z 343[\mathrm{M}+\mathrm{Na}]^{+}$; HRESIMS $\mathrm{m} / \mathrm{z}$ 343.2244 [M + Na] $]^{+}$(calcd. for $\mathrm{C}_{20} \mathrm{H}_{32} \mathrm{O}_{3} \mathrm{Na}, 343.2244$ ).

Nanolobol C (5): colorless oil; $[\alpha]_{\mathrm{D}}^{25}-86\left(c 0.20, \mathrm{CHCl}_{3}\right)$; IR (neat) $v_{\max } 3384,2959,2874,1724$, 1601, 1438, 1367, 1256, and $1095 \mathrm{~cm}^{-1} ;{ }^{13} \mathrm{C}$ and ${ }^{1} \mathrm{H}$ NMR data, see Table 2; ESIMS $\mathrm{m} / z 403[\mathrm{M}+\mathrm{Na}]^{+}$; HRESIMS $m / z$ 403.2456 [M + Na] ${ }^{+}$(calcd. for $\left.\mathrm{C}_{22} \mathrm{H}_{36} \mathrm{O}_{5} \mathrm{Na}, 403.2455\right)$.

Calyculone I (6): colorless needles; $[\alpha]_{\mathrm{D}}^{25}+41\left(\right.$ c 1.09, $\left.\mathrm{CHCl}_{3}\right)$; lit. $[\alpha]_{\mathrm{D}}^{20}+52.1$ (c 1.0, $\left.\mathrm{CHCl}_{3}\right)$ [5]; IR (neat) $v_{\max } 2959,1708,1463,1385$ and $897 \mathrm{~cm}^{-1}$; ESIMS $\mathrm{m} / z 455[\mathrm{M}+\mathrm{Na}]^{+}$(calcd. for $\mathrm{C}_{20} \mathrm{H}_{32} \mathrm{O}_{2} \mathrm{Na}$ ).

Sinulariol A (7): colorless oil; $[\alpha]_{\mathrm{D}}^{21}+47\left(\mathrm{c} 0.95, \mathrm{CHCl}_{3}\right)$; lit. $[\alpha]_{\mathrm{D}}^{24}+17.1$ (c 0.79, $\left.\mathrm{CHCl}_{3}\right)[13]$; IR (neat) $v_{\max } 3369,2959,2871,1447,1379$ and $756 \mathrm{~cm}^{-1}$; ESIMS m/z $345[\mathrm{M}+\mathrm{Na}]^{+}$(calcd. for $\mathrm{C}_{20} \mathrm{H}_{34} \mathrm{O}_{3} \mathrm{Na}$ ).

Sinulariol C (8): colorless oil; $[\alpha]_{\mathrm{D}}^{25}-30\left(c 0.31, \mathrm{CHCl}_{3}\right)$; lit. [ $\left.\alpha\right]_{\mathrm{D}}^{22}-8.8\left(\mathrm{c} 0.15, \mathrm{CHCl}_{3}\right)[13]$; IR (neat) $v_{\max } 3421,2960,1671,1458,1384,1021,857,755$ and $669 \mathrm{~cm}^{-1}$; ESIMS m/z $327[\mathrm{M}+\mathrm{Na}]^{+}$(calcd. for $\mathrm{C}_{20} \mathrm{H}_{32} \mathrm{O}_{2} \mathrm{Na}$ ).

Sinulariol D (9): colorless oil; $[\alpha]_{\mathrm{D}}^{25}+13\left(\right.$ c $\left.0.46, \mathrm{CHCl}_{3}\right)$; lit. $[\alpha]_{\mathrm{D}}^{24}+7.5$ (c 1.35, $\left.\mathrm{CHCl}_{3}\right)$ [13]; IR (neat) $v_{\max } 3355,2963,2873,1653,1455,1367,1077$ and $756 \mathrm{~cm}^{-1}$; ESIMS m/z $361[\mathrm{M}+\mathrm{Na}]^{+}$(calcd. for $\mathrm{C}_{20} \mathrm{H}_{34} \mathrm{O}_{4} \mathrm{Na}$ ).

Sinulariol H (10): colorless oil; $[\alpha]_{\mathrm{D}}^{21}-78\left(\right.$ c $\left.0.73, \mathrm{CHCl}_{3}\right)$; lit. $[\alpha]_{\mathrm{D}}^{24}-71.3$ (c $\left.0.28, \mathrm{CHCl}_{3}\right)$ [13]; IR (neat) $v_{\max } 3371,2963,2933,1444,1374$ and $756 \mathrm{~cm}^{-1}$; ESIMS $\mathrm{m} / z 361[\mathrm{M}+\mathrm{Na}]^{+}$(calcd. for $\mathrm{C}_{20} \mathrm{H}_{34} \mathrm{O}_{4} \mathrm{Na}$ ).

Sinulariol J (11): colorless oil; $[\alpha]_{\mathrm{D}}^{21}-77\left(\right.$ c $\left.0.65, \mathrm{CHCl}_{3}\right)$; lit. $[\alpha]_{\mathrm{D}}^{23}-40.5$ (c $\left.0.15, \mathrm{CHCl}_{3}\right)$ [13]; IR (neat) $v_{\max } 3350,2959,2871,1447,1379$ and $756 \mathrm{~cm}^{-1}$; ESIMS $\mathrm{m} / z 361[\mathrm{M}+\mathrm{Na}]^{+}$(calcd. for $\mathrm{C}_{20} \mathrm{H}_{34} \mathrm{O}_{4} \mathrm{Na}$ ). 


\subsection{Crystallographic Data of 6}

The colorless crystal size of $0.15 \times 0.10 \times 0.10 \mathrm{~mm}$ was obtained at $4{ }^{\circ} \mathrm{C}$ in a refrigerator by slow evaporation in an acetone solution. Diffraction intensity data were acquired with a CCD area detector with graphite-monochromated $\mathrm{Cu} \mathrm{K} \alpha$ radiation $\left(\lambda=1.54178 \AA\right.$ ). Crystal data for 6: $\mathrm{C}_{20} \mathrm{H}_{32} \mathrm{O}_{2}$, $\mathrm{M}=304.45$, monoclinic, $a=8.4794$ (6) $\AA, b=11.0386$ (8) $\AA, c=10.2704$ (7) $\AA, \alpha=90^{\circ}, \beta=104.094(3)^{\circ}$, $\gamma=90^{\circ}, V=932.38$ (11) $\AA 3, T=100$ (2) $\mathrm{K}$, space group $P 22_{1}, Z=2, \mu(\mathrm{CuK} \alpha)=0.521 \mathrm{~mm}^{-1}$, 6301 reflections collected, 3100 independent reflections $\left(R_{i n t}=0.0201\right)$. The final $R_{1}$ values were $0.0275(I>2 \sigma(I))$. The final $w R\left(F_{2}\right)$ values were $0.0733(I>2 \sigma(I))$. The final $R_{1}$ values were 0.0276 (all data). The final $w R\left(F_{2}\right)$ values were 0.0734 (all data). The goodness of fit on $F_{2}$ was 1.050 . Flack parameter $=0.1$ (2). Crystallographic data for 6 have been deposited with the Cambridge Crystallographic Data Centre (deposition number CCDC 1482769). Copies of the data can be obtained, free of charge, on application to the Director, CCDC, 12 Union Road, Cambridge CB21EZ, UK.

\subsection{Cytotoxicity Assay}

The Alamar Blue assay were performed as previous reported [14,15]. After the cell lines (P388, K562, and HT-29) were cultured for $15 \mathrm{~h}$ according to the published procedure [16], the tested compounds in DMSO solutions were added and cultured for $72 \mathrm{~h}$. The attached cells were incubated with Alamar Blue (10 $\mu \mathrm{L} /$ well, $4 \mathrm{~h})$ and the absorbance was measured at wavelength of $595 \mathrm{~nm}$ using a microplate reader.

\subsection{Nitric Oxide Inhibitory Activity}

The nitrite concentration in the culture medium was measured as an indicator of NO production according to the Griess reaction [17]. Briefly, $80 \mu \mathrm{L}$ of cell culture supernatant was reacted with $100 \mu \mathrm{L}$ of Griess reagent (1:1 mixture of $0.1 \% \mathrm{~N}$-(1-naphthyl)ethylenediamine dihydrochloride in water and $1 \%$ sulfanilamide in $5 \%$ phosphoric acid) in a 96-well plate and incubated at room temperature for $10 \mathrm{~min}$. The absorbance at $550 \mathrm{~nm}$ was recorded using the ELISA reader [18,19]. Fresh medium was used as the blank. The results are expressed as the percentage of inhibition calculated relative to the cells treated with vehicle and LPS.

\section{Conclusions}

The prior studies demonstrated that the cubitanoids originating from marine organisms were elaborated as a minor group in certain species, such as gorgonian corals, Eunicea calyculata $[3,4]$ and E. laciniata [20], and soft corals, Sinularia triangula [21,22] and S. crassa [23]. Our present study discovered new cubitanoids from the $S$. nanolobata, collected off the coast of the eastern region of Taiwan. Considering our prior work on the same species collected in different locations of Taiwan water $[11,12]$, it is noteworthy that the metabolites from soft corals, even the skeletons, might vary with their geographical location.

Supplementary Materials: HRESIMS, ${ }^{1} \mathrm{H}$, and ${ }^{13} \mathrm{C}$ spectra of new compounds $\mathbf{1 - 5}$ are available online at www.mdpi.com/1660-3397/14/8/150/s1. Figure S1: HRESIMS spectrum of 1, Figure S2: ${ }^{1} \mathrm{H}$ NMR spectrum of 1 in $\mathrm{CDCl}_{3}$ at $400 \mathrm{MHz}$, Figure S3: ${ }^{13} \mathrm{C}$ NMR spectrum of $\mathbf{1}$ in $\mathrm{CDCl}_{3}$ at $100 \mathrm{MHz}$, Figure S4: HRESIMS spectrum of 2, Figure S5: ${ }^{1} \mathrm{H}$ NMR spectrum of 2 in $\mathrm{CDCl}_{3}$ at $400 \mathrm{MHz}$, Figure S6: ${ }^{13} \mathrm{C}$ NMR spectrum of 2 in $\mathrm{CDCl}_{3}$ at $100 \mathrm{MHz}$, Figure S7: HRESIMS spectrum of 3, Figure S8: ${ }^{1} \mathrm{H}$ NMR spectrum of 3 in $\mathrm{CDCl}_{3}$ at $400 \mathrm{MHz}$, Figure S9: ${ }^{13} \mathrm{C}$ NMR spectrum of 3 in $\mathrm{CDCl}_{3}$ at $100 \mathrm{MHz}$, Figure S10: HRESIMS spectrum of 4, Figure S11: ${ }^{1} \mathrm{H}$ NMR spectrum of 4 in $\mathrm{CDCl}_{3}$ at $400 \mathrm{MHz}$, Figure S12: ${ }^{13} \mathrm{C}$ NMR spectrum of 4 in $\mathrm{CDCl}_{3}$ at $100 \mathrm{MHz}$, Figure S13: HRESIMS spectrum of 5, Figure S14: ${ }^{1} \mathrm{H}$ NMR spectrum of 5 in $\mathrm{CDCl}_{3}$ at $500 \mathrm{MHz}$, Figure S15: ${ }^{13} \mathrm{C}$ NMR spectrum of 5 in $\mathrm{CDCl}_{3}$ at $125 \mathrm{MHz}$.

Acknowledgments: This work was supported by grants from Ministry of Science and Technology (MOST 104-2320-B-110-001-MY2 and MOST 104-2113-M-110-006), NSYSU-KMU Joint Research Project (NSYSUKMU 105-I008) and Aim for the TOP University Program (04C030205) from Ministry of Education of Taiwan awarded to Jyh-Horng Sheu. 
Author Contributions: Jyh-Horng Sheu designed and guided the whole experiment. Chih-Hua Chao contributed to structure elucidation and manuscript preparation. Chia-Yun $\mathrm{Wu}$ isolated the compounds and performed data acquisition and structure elucidation. Chiung-Yao Huang and Yang-Chang Wu performed the cytotoxicity assay, structure elucidation, and data analysis. Hui-Chun Wang performed the nitric oxide inhibitory assay. Chang-Feng Dai contributed to the collection of soft coral and species identification.

Conflicts of Interest: The authors declare no conflict of interest.

\section{References}

1. Wefer, J.; Simon, K.; Lindel, T. Cubitane: A rare diterpenoid skeleton. Phytochem. Rev. 2013, 12, 95-105. [CrossRef]

2. Prestwich, G.D.; Wiemer, D.F.; Meinwald, J.; Clardy, J. Cubitene: An irregular twelve-membered-ring diterpene from a termite soldier. J. Am. Chem. Soc. 1978, 100, 2560-2561. [CrossRef]

3. Look, S.A.; Fenical, W.; Zheng, Q.T.; Clardy, J. Calyculones, new cubitane diterpenoids from the Caribbean gorgonian octocoral Eunicea calyculata. J. Org. Chem. 1984, 49, 1417-1423. [CrossRef]

4. Shin, J.; Fenical, W. New diterpenoids from the Caribbean gorgonian Eunicea calyculata. Photochemical interconversion of the cembrene and cubitene skeletons. J. Org. Chem. 1991, 56, 1227-1233. [CrossRef]

5. Wei, X.; Nieves, K.; Rodríguez, A.D. Bioactive cubitane diterpenoids from a Colombian gorgonian species of the genus Eunicea. Pure Appl. Chem. 2012, 84, 1847-1855. [CrossRef]

6. Stojković, D.; Soković, M.; Glamoćlija, J.; Džamić, A.; Ćirić, A.; Ristić, M.; Grubišić, D. Chemical composition and antimicrobial activity of Vitex agnus-castus L. fruits and leaves essential oils. Food Chem. 2011, 128, 1017-1022. [CrossRef]

7. Huang, C.Y.; Sung, P.J.; Uvarani, C.; Su, J.H.; Lu, M.C.; Hwang, T.L.; Dai, C.F.; Wu, S.L.; Sheu, J.H. Glaucumolides A and B, biscembranoids with new structural type from a cultured soft coral Sarcophyton glaucum. Sci. Rep. 2015, 5, 15624-15632. [CrossRef] [PubMed]

8. Tsai, T.C.; Chen, H.Y.; Sheu, J.H.; Chiang, M.Y.; Wen, Z.H.; Dai, C.F.; Su, J.H. Structural elucidation and structure-anti-inflammatory activity relationships of cembranoids from cultured soft coral Sinularia sandensis and Sinularia flexibilis. J. Agric. Food Chem. 2015, 63, 7211-7218. [CrossRef] [PubMed]

9. Fang, H.F.; Hsu, C.H.; Chao, C.H.; Wen, Z.H.; Wu, Y.C.; Dai, C.F.; Sheu, J.H. Cytotoxic and anti-inflammatory metabolites from the soft coral Scleronephthya gracillimum. Mar. Drugs 2013, 11, 1853-1865. [CrossRef] [PubMed]

10. Chao, C.H.; Chou, K.J.; Huang, C.Y.; Wen, Z.H.; Hsu, C.H.; Wu, Y.C.; Dai, C.F.; Sheu, J.H. Bioactive cembranoids from the soft coral Sinularia crassa. Mar. Drugs 2011, 9, 1955-1968. [CrossRef] [PubMed]

11. Atallah, F.A.; Su, J.H.; Shiue, R.T.; Pan, X.J.; Dai, C.F.; Kuo, Y.H.; Sheu, J.H. New $\beta$-caryophyllene-derived terpenoids from the soft coral Sinularia nanolobata. J. Nat. Prod. 2004, 67, 592-597.

12. Tseng, Y.J.; Wen, Z.H.; Dai, C.F.; Chiang, M.Y.; Sheu, J.H. Nanolobatolide, a new C18 metabolite from the Formosan soft coral Sinularia nanolobata. Org. Lett. 2009, 11, 5030-5032. [CrossRef] [PubMed]

13. Lai, D.; Li, Y.; Xu, M.; Deng, Z.; van Ofwegen, L.; Qian, P.; Proksch, P.; Lin, W. Sinulariols A-S, 19-oxygenated cembranoids from the Chinese soft coral Sinularia rigida. Tetrahedron 2011, 67, 6018-6029. [CrossRef]

14. O'Brien, J.; Wilson, I.; Orton, T.; Pognan, F. Investigation of the Alamar Blue (resazurin) fluorescent dye for the assessment of mammalian cell cytotoxicity. Eur. J. Biochem. 2000, 267, 5421-5426. [CrossRef] [PubMed]

15. Nakayama, G.R.; Caton, M.C.; Nova, M.P.; Parandoosh, Z. Assessment of the Alamar Blue assay for cellular growth and viability in vitro. J. Immunol. Methods 1997, 204, 205-208. [CrossRef]

16. Chao, C.H.; Huang, T.Z.; Wu, C.Y.; Chen, B.W.; Huang, C.Y.; Hwang, T.L.; Dai, C.F.; Sheu, J.H. Steroidal and $\alpha$-tocopherylhydroquinone glycosides from two soft corals Cladiella hirsuta and Sinularia nanolobata. RSC Adv. 2015, 5, 74256-74262. [CrossRef]

17. Kim, H.K.; Cheon, B.S.; Kim, Y.H.; Kim, S.Y.; Kim, H.P. Effects of naturally occurring flavonoids on nitric oxide production in the macrophage cell line RAW 264.7 and their structure-activity relationships. Biochem. Pharmacol. 1999, 58, 759-765. [CrossRef]

18. Schmidt, H.H.W.; Kelm, M. Determination of nitrite and nitrate by the Griess reaction. In Methods in Nitric Oxide Research; Feelisch, M., Stamler, J., Eds.; Wiley: Chichester, UK, 1996; pp. 491-497.

19. Hsieh, Y.H.; Kuo, P.M.; Chien, S.C.; Shyur, L.F.; Wang, S.Y. Effects of Chamaecyparis formosensis Matasumura extractives on lipopolysaccharide-induced release of nitric oxide. Phytomedicine 2007, 14, 675-680. [CrossRef] [PubMed] 
20. Marville, K.I.; Reynolds, W.F.; Sealy, R.L.; Tinto, W.F. Terpenoid metabolites of the marine octocoral Eunicea laciniata. Heterocycles 2004, 63, 107-113. [CrossRef]

21. Lu, M.C.; Lee, N.L.; Tseng, S.W.; Su, J.H. Sinutriangulin A, a novel diterpenoid from the soft coral Sinularia triangula. Tetrahderon Lett. 2011, 52, 5869-5871. [CrossRef]

22. Su, H.J.; Lee, N.L.; Lu, M.C.; Su, J.H. Triangulene C, a new cubitane-based Diterpenoid from the Soft Coral Sinularia triangula. Nat. Prod. Commun. 2012, 7, 479-480. [PubMed]

23. Cheng, C.H.; Lin, Y.S.; Wen, Z.H.; Su, J.H. A new cubitane diterpenoid from the soft coral Sinularia crassa. Molecules 2012, 17, 10072-10078. [CrossRef] [PubMed] article distributed under the terms and conditions of the Creative Commons Attribution (CC-BY) license (http:/ / creativecommons.org/licenses/by/4.0/). 